\title{
PENGARUH KOMPETENSI WIRAUSAHA, KREATIVITAS DAN PENGGUNAAN MEDIA SOSIAL TERHADAP PERKEMBANGAN USAHA KERAJINAN BATU PADAS BANJAR SILAKARANG, GIANYAR
}

\author{
Oleh: \\ Ni Ketut Arniti \\ Universitas Pendidikan Nasional Denpasar \\ Email : Ketutarniti@undiknas.ac.id
}

\begin{abstract}
This research was conducted to determine the effect of entrepreneurial competence on the development of Padas Stone Crafts, the influence of creativity on the development of Padas Stone Crafts and the influence of the use of social media on the development of the Padas Stone Craft Business. This research was conducted on a number of Padas Stone Carving Art Crafts in the Banjar Silakarang, Sukawati, Gianyar Bali. Data collection was conducted with a questionnaire to 36 respondents. The collected data was analyzed by multiple linear regression, analysis of determination and significance test with $t$ test. The results showed that 1) The amount of the t-count for the entrepreneurial competency variable was 4.702> t table 1.697 with a significance level of 0.000 . This means that partially entrepreneurial competence has a real influence on the development of the Craft Business. 2) The amount of the tcount for the creativity variable is 2.962> ttable 1.697 with a significance level of 0.006 . This means that partially creativity has a real influence on the development of the Craft Business. 3) The amount of the tcount for the variable social media use is 2.116>t table 1.697 with a significance level of 0.042 . This means that partially the use of social media has a real influence on the development of the Craft Business.
\end{abstract}

Keywords: entrepreneurial competence, creativity, social media and the development of business

\section{PENDAHUALUAN}

Perkembangan pelaku bisnis yang terjadi pada saat era global seperti sekarang ini, ditandai dengan adanya persaingan yang semakin kompetitif. Hal utama yang harus dimiliki oleh seorang wirausaha di era persaingan seperti saat ini adalah kreativitas. Wirausaha diharapkan memiliki kreativitas menarik serta mampu menguasai banyak informasi dari berbagi hal. Selain itu seorang wirausaha harus memiliki keahlian ataupun skill yang berbeda dari wirausaha-wirausaha yang lain. Kemampuan diri dari seorang wirausaha menjadi ciri khas yang unik dari produk-produk yang dihasilkannya, dan diharapkan akan mampu menghadapi persaingan yang tidak dapat diprediksi.

Tidak mudah mencapai hasil yang maksimal serta berhasil dalam menjalankan bisnis. Karena itu seorang wirausaha harus mampu menguasai banyak hal tentang pengelolaan usaha. Seorang entrepreneur yang http://ejurnal.binawakya.or.id/index.php/MBI sukses adalah entrepreneur yang memiliki pengetahuan, skill atau keterampilan, serta kualitas pribadi dari seorang wirausaha, seperti nilai, sikap, serta attidute, atau sikap dan tingkah laku yang diperlukan dalam menjalankan atau melaksanakan suatu pekerjaan ataupun kegiatan.

Penelitian kali ini dilakukan di Kabupaten Gianyar, Bali, karena Bali merupakan salah satu dari 33 provinsi di Indonesia yang menyumbang pertumbuhan ekonomi tertinggi di Indonesia. Seni ukir batu merupakan salah satu kreativitas seni yang dimiliki oleh orang-orang Bali. Seni ukir batu ini merupakan seni kerajinan tangan yang dikembangkan di Bali, khususnya Kabupaten Gianyar. Objek yang dipilih dalam penelitian ini adalah pengusaha kerajinan batu padas yang ada di Dusun Silakarang, Singapadu, Sukawati, Gianyar. Alasan dipilihnya lokasi ini karena perajin seni ukir batu khususnya batu padas di Banjar Silakarang belum melakukan upaya-upaya untuk mengembangkan usahanya

Vol.13 No.11 Juni 2019 
dan produk mereka. Perajin tangang seni ukiran batu dalam hal ini batu padas, khususnya yang ada di Banjar Silakarang, Singapadu, Gianyar, masih menggunakan pola lama. Pola lama yang dipakai oleh perajin tersebut diantaranya, hanya baru sebatas membuat ukiran di tempat suci seperti pura atau yang lainnya serta dalam bentuk patung (togog). Para perajin ini belum mampu beradaptasi dengan pangsa pasar yang lebih luas dan lebih modern.

Segmen pasar modern tersebut diantaranya seperti ukiran dinding (patung dan relief) yang dibuat pada bangunan modern seperti hotel, gedung pertokoan, gedung perkantoran, pondok wisata, restauran, serta bangunan penunjang akomodasi pariwisata lainnya. Beberapa kendala yang dihadapi perajin seni ukir batu khususnya batu padas di Banjar Silakarang yang disebabkan kurangnya kompetensi wirausaha seperti: masih menjalankan aturan bisnis yang sama dari waktu ke waktu, berdasarkan pengalaman turun temurun, padahal aturan tersebut tidak sesuai lagi dengan kondisi pasar saat ini. Kendala pada alat produksi yang terbatas mengakibatkan terbatasnya produk yang perajin hasilkan, kendala ini menyebabkan terjadinya faktor internal yang dapat mempengaruhi pengembangan usaha.

Kreativitas adalah kemampuan yang dimiliki oleh seorang manusia agar mampu mengubah sesuatu yang sudah ada menjadi lebih menarik. Setiap entrepreneur harus memiliki kreativitas agar mampu menciptakan produk yang lebih menarik di mata pelanggan. Wolfook (1984) memberikan batasan bahwa kreativitas merupakan pengetahuan yang dimiliki seseorang dalam menciptakan ataupun menghasilkan sesuatu yang baru ataupun kemampuan yang dimiliki oleh seseorang untuk memecahkan suatu masalah. Dengan adanya jiwa kreativitas yang tinggi, para wirausahawan dapat mengubah barang yang sudah ada menjadi barang yang lebih menarik baik dilihat dari segi bentuk maupun dari segi keindahannya. Namun sayangnya, tidak banyak perajin seni ukir batu khususnya batu padas di Banjar Silakarang yang memiliki jiwa kreativitas yang tinggi.

Vol.13 No.11 Juni 2019
Kendala lain yang dihadapi oleh para perajin, dalam hal ini perajin batu khususnya batu padas yang ada di Banjar Silakarang, Singapadu, dalam memasarkan produknya masih menggunakan cara-cara lama. Cara-cara lama tersebut diantaranya, hanya memasarkan produkproduknya melalui kios-kios ataupun melalui art shop. Selain itu juga menjual produk-produknya melalui pengepul. Karena itu di era yang serba digital seperti saat ini, para perajin harus mampu memanfaatkan media yang ada dalam memasarkan produk-produknya.

Berdasarkan penjelasan tersebut, maka dapat dijabarkan pokok permasalahan, yaitu:

1. Apakah ada pengaruh kompetensi wirausaha terhadap perkembangan Usaha kerajinan batu padas di Banjar Silakarang, Kecamatan Sukawati, Kabupaten Gianyar, Bali?

2. Apakah ada pengaruh kreativitas wirausaha terhadap perkembangan Usaha Kerajinan batu padas di Banjar Silakarang, Kecamatan Sukawati, Kabupaten Gianyar, Bali?

3. Apakah ada pengaruh penggunaan media sosial terhadap perkembangan Usaha Kerajinan batu padas di Banjar Silakarang, Kecamatan Sukawati, Kabupaten Gianyar, Bali?

\section{LANDASAN TEORI}

\section{Pengertian Kompetensi Wirausaha}

Guna mencapai hasil yang maksimal dalam dunia bisnis serta sukses dalam bisnis merupakan sesuatu hal yang tidak mudah. Banyak hal yang harus dipahami serta diketahui oleh para pebisnis. Menurut Fithri dan Amanda (2012) kompetensi diartikan sebagai pengetahuan, keterampilan dan kemampuan individu yang langsung berpengaruh pada kinerja. Sehingga dapat diartikan bahwa wirausaha yang sukses adalah seseorang yang memiliki ilmu pengetahuan, keterampilan dan kualitas individu yang meliputi sikap, nilai, serta tingkah laku yang diperlukan untuk melaksakanan pekerjaan atau kegiatan.

http://ejurnal.binawakya.or.id/index.php/MBI 
Menurut Heru (2009), disebutkan juga

bahwa kompetensi wirausaha terbagi menjadi 7 , antara lain:

1. Kompetensi hubungan antar manusia

2. Kompetensi teknik

3. Kompetensi marketing

4. Kompetensi keuangan

5. Kompetensi konseptual

6. Kompetensi dalam pengambilan keputusan

7. Kompetensi dalam mengatur waktu

\section{Pengertian Kreativitas}

Kreativitas belajar adakalanya dianggap sebagai sesuatu ketrampilan yang didasarkan pada bakat alam, karena mereka yang berbakat saja yang bisa menjadi kreatif. Anggapan tersebut tidak sepenuhnya benar, walaupun dalam kenyataannya terlihat bahwa orang tertentu memiliki kemampuan untuk menciptakan ide baru dengan cepat dan beragam. Sesungguhnya kemampuan berpikir kreatif pada dasarnya dimiliki semua orang. Menurut Munandar (2012) kreativitas sebagai kemampuan untuk menciptakan sesuatu yang baru, sebagai kemampuan untuk memberi gagasan baru yang dapat diterapkan dalam pemecahan masalah, atau sebagai kemampuan untuk melihat hubungan baru antara unsur yang sudah ada sebelumnya. Kreativitas seseorang dapat dilihat dari tingkah laku atau kegiatannya yang kreatif.

Menurut Slamet (2010) bahwa yang penting dalam kreativitas bukanlah penemuan sesuatu yang belum pernah diketahui orang sebelumnya, melainkan bahwa produk kreativitas merupakan sesuatu yang baru bagi diri sendiri dan tidak harus merupakan sesuatu yang baru bagi orang lain atau dunia pada umumnya. Menurut Gallagher dalam Rachmawati (2005) mengatakan bahwa "Creativity is a mental process by which an individual crates new ideas or products, or recombines existing ideas and product, in fashion that is novel to him or her " (kreativitas merupakan suatu proses mental yang dilakukan individu berupa gagasan ataupun produk baru, atau mengkombinasikan antara keduanya yang pada akhirnya akan melekat pada dirinya).

http://ejurnal.binawakya.or.id/index.php/MBI
Supriadi dalam Rachmawati (2005) mengutarakan bahwa kreativitas adalah kemampuan seseorang untuk melahirkan sesuatu yang baru, baik berupa gagasan maupun karya nyata yang relatif berbeda dengan apa yang telah ada. Kreativitas merupakan kemampuan berpikir tingkat tinggi yang mengimplikasikan terjadinya eskalasi dalam kemampuan berpikir, ditandai oleh suksesi, diskontinuitas, diferensiasi, dan integrasi antara tahap perkembangan. Menurut Semiawan dalam Rachmawati bahwa kreativitas merupakan kemampuan untuk memberikan gagasan baru dan menerapkannya dalam pemecahan masalah.

Chaplin dalam Rachmawati (2005) mengutarakan bahwa kreativitas adalah kemampuan menghasilkan bentuk baru dalam seni, atau dalam permesinan, atau dalam pemecahan masalah-masalah dengan metodemetode baru. Menurut Kuper dan Kuper (2012) kreativitas merupakan sebuah konsep yang majemuk dan multidimensial, sehingga sulit didefinisikan secara operasional. Definisi sederhana yang sering digunakan secara luas tentang kreativitas adalah kemampuan untuk menciptakan sesuatu yang baru.

\section{Pengertian Sosial Media}

Menurut Gunelius (2011) sosial media merupakan suatu bentuk pemasaran langsung ataupun tidak langsung yang digunakan untuk membangun kesadaran, pengakuan, daya ingat, dan tindakan untuk merek, bisnis, produk, orang, atau entitas lainnya dan dilakukan dengan menggunakan alat dari web sosial seperti blogging, microblogging, social networking, social bookmarking, dan content sharing. Social media marketing adalah sebuah proses yang mendorong individu untuk melakukan promosi melalui situs web, produk, atau layanan mereka melalui saluran sosial online dan untuk berkomunikasi dengan memanfaatkan komunitas yang jauh lebih besar yang memiliki kemungkinan lebih besar untuk melakukan pemasaran daripada melalui saluran periklanan tradisional (Weinberg, 2016). Sosial media merupakan bentuk periklanan secara online yang menggunakan konteks kultural dari komunitas

Vol.13 No.11 Juni 2019

\section{Open Journal Systems}


sosial meliputi jejaring sosial, dunia virtual, situs berita sosial, dan situs berbagi pendapat sosial untuk menemui tujuan komunikasi (Tuten, 2008).

Menurut Gunelius (2011) terdapat empat elemen yang dijadikan sebagai variabel kesuksesan sosial media:

1. Konten yang menarik

2. Membagikan konten kepada komunitas sosial

3. Connecting jejaring sosial

4. Community building web sosial media

\section{Pengertian Perkembangan UKM}

Pengembangan suatu usaha adalah tanggung jawab dari setiap pengusaha atau wirausaha yang membutuhkan pandangan ke depan, motivasi dan kreativitas (Anoraga, 2007). Jika hal ini dapat dilakukan oleh setiap wirausaha, maka besarlah harapan untuk dapat menjadikan usaha yang semula kecil menjadi skala menengah bahkan menjadi sebuah usaha besar. Pengembangan UKM dilakukan dengan cara peningkatan skala ekonomis. Cara ini dapat dilakukan dengan menambah skala produksi, tenaga kerja, teknologi, sistem distribusi, dan tempat usaha (Suryana, 2006). Ini dilakukan bila perluasan usaha atau peningkatan output akan menurunkan biaya jangka panjang, yang berarti mencapai skala ekonomis (economics of scale). Sebaliknya, bila peningkatan output mengakibatkan peningkatan biaya jangka panjang (diseconomics of scale), maka tidak baik untuk dilakukan. Dengan kata lain, bila produk barang dan jasa yang dihasilkan sudah mencapai titik paling efisien, maka memperluas skala ekonomi tidak bisa dilakukan, sebab akan mendorong kenaikan biaya. Skala usaha ekonomi terjadi, apabila perluasan usaha atau peningkatan output menurunkan biaya jangka panjang. Karena itu, apabila terjadi skala usaha yang tidak ekonomis, wirausaha dapat meningkatkan usahanya dengan memperluas cakupan usaha (economics of scope). Skala ekonomi menunjukkan pengurangan biaya perusahaan akibat kenaikan output, maka kurva pengalaman atau kurva belajar (learning curve) menunjukkan pengurangan biaya yang mucul akibat kenaikan volume secara kumulatif.
Kerangka Pemikiran

Pengaruh Kompetensi Wirausaha, Kreativitas dan Penggunaan Media Sosial Terhadap Perkembangan UKM

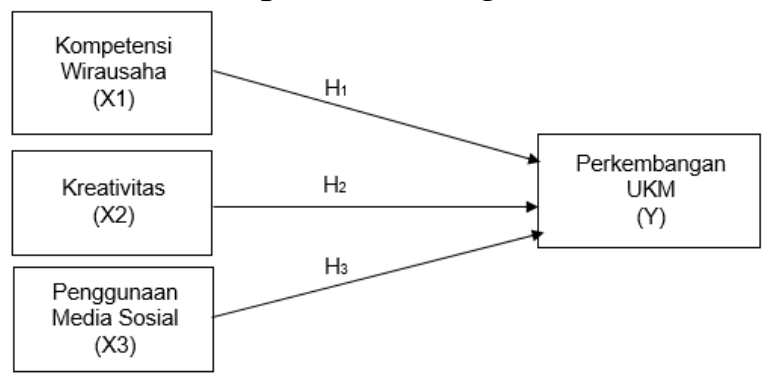

Hipotesis

Berdasarkan kerangka pikir dan landasan teori serta kajian penelitian terdahulu, maka dapat hipotesis dalam penelitian ini adalah:

H1 : Kompetensi wirausaha berpengaruh positif terhadap perkembangan Usaha Kerajinan Batu Padas

H2 : Kreativitas berpengaruh positif terhadap perkembangan Usaha Kerajinan Batu Padas

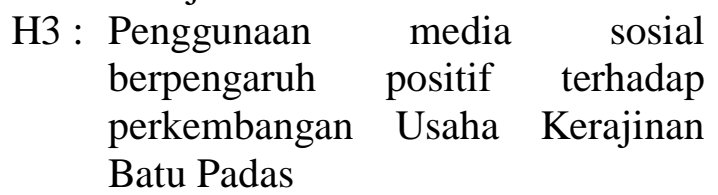

\section{METODE PENELITIAN}

Penelitian ini dilakukan pada beberapa Usaha Kerajinan Seni Ukir Batu Padas pada Banjar Silakarang, Sukawati, Gianyar, Bali. Teknik pengumpulan data menggunakan kuesioner kepada 36 orang responden. Analisis data yang digunakan dalam penelitian ini adalah regresi linier berganda, analisis determinasi dan uji signifikansi dengan uji t.

\section{HASIL DAN PEMBAHASAN}

Analisis koefesien regresi linier berganda

Analisis regresi linier berganda ini digunakan untuk mengetahui besarnya pengaruh kompetensi wirausaha, kreativitas dan penggunaan media sosial terhadap perkembangan Usaha Kerajinan Seni Ukir Batu Padas Banjar Silakarang, Singapadu, Kecamatan Sukawati, Kabupaten Gianyar, Bali.

http://ejurnal.binawakya.or.id/index.php/MBI 
Dari hasil pengolahan data dengan program SPSS for windows maka diperoleh nilai seperti pada tabel 1 berikut ini.

Tabel 1. Nilai Coefficients Variabel Kompetensi Wirausaha, Kreativitas dan Penggunaan Media Sosial

\begin{tabular}{|l|r|r|r|}
\hline \multirow{2}{*}{ Model } & \multicolumn{2}{|c|}{ Unstandardized Coefficients } & \multicolumn{2}{c|}{$\begin{array}{c}\text { Standardized } \\
\text { Coefficients }\end{array}$} \\
\cline { 2 - 4 } & \multicolumn{1}{|c|}{ B } & \multicolumn{1}{c|}{ Std. Error } & \multicolumn{1}{c|}{ Beta } \\
\hline $\begin{array}{l}\text { (Constant) } \\
\begin{array}{l}\text { Kompetensi } \\
\text { Wirausaha }\end{array}\end{array} \quad .1 .326$ & 1.233 & \\
\hline Kreativitas & .562 & .120 & .559 \\
\hline $\begin{array}{l}\text { Penggunaan Media } \\
\text { Sosial }\end{array}$ & .174 & .122 & .336 \\
\hline
\end{tabular}

Sumber: Lampiran 10

Berdasarkan data pada tabel 4.8 di atas maka dapat dibuat persamaan seperti berikut ini. $0,174 X_{3}$

$$
\mathrm{Y}=-1,326+0,562 \mathrm{X}_{1}+0,363 \mathrm{X}_{2}+
$$

Persamaan regresi tersebut dapat dijelaskan sebagai berikut.

1) Nilai konstanta sebesar $-1,326$ menggambarkan bahwa jika kompetensi wirausaha, kreativitas dan penggunaan media sosial sama dengan 0 maka perkembangan usaha batu padas Banjar Silakarang, Singapadu, Kecamatan Sukawati adalah sebesar $-1,326$ satuan.

\section{2)}

Koefisien regresi variabel kompetensi wirausaha sebesar 0,562 mempunyai makna bahwa setiap perubahan atau peningkatan 1 (satu) satuan kompetensi wirausaha, maka perkembangan usaha batu padas Banjar Silakarang, Singapadu, Kecamatan Sukawati akan meningkat sebesar 0,562, demikian pula sebaliknya, apabila kompetensi wirausaha dikurangi (satu) satuan, maka perkembangan usaha batu padas Banjar Silakarang, Singapadu, Kecamatan Sukawati juga akan menurun. Perubahan tersebut menunjukkan adanya pengaruh yang positif antara kompetensi wirausaha terhadap perkembangan usaha batu padas Banjar Silakarang, Singapadu, Kecamatan Sukawati.

3) Koefisien regresi variabel kreativitas sebesar 0,363 mempunyai makna bahwa setiap perubahan atau peningkatan 1 (satu) satuan kreativitas, maka perkembangan usaha batu padas Banjar Silakarang, Singapadu, Kecamatan Sukawati akan meningkat sebesar 0,363, demikian pula sebaliknya, apabila kreativitas dikurangi (satu) satuan, maka perkembangan usaha batu padas Banjar Silakarang, Singapadu, Kecamatan Sukawati juga akan menurun. Perubahan tersebut menunjukkan adanya pengaruh yang positif antara kreativitas terhadap perkembangan usaha batu padas Banjar Silakarang, Singapadu, Kecamatan Sukawati.

4) Koefisien regresi variabel penggunaan media sosial sebesar 0,174 mempunyai makna bahwa setiap perubahan atau peningkatan 1 (satu) satuan penggunaan media sosial, maka perkembangan usaha batu padas Banjar Silakarang, Singapadu, Kecamatan Sukawati akan meningkat sebesar 0,174. Demikian pula sebaliknya, apabila penggunaan media sosial dikurangi (satu) satuan, maka perkembangan usaha batu padas Banjar Silakarang, Singapadu, Kecamatan Sukawati juga akan menurun. Perubahan tersebut menunjukkan adanya pengaruh yang positif antara penggunaan media sosial terhadap perkembangan usaha batu padas Banjar Silakarang, Singapadu, Kecamatan Sukawati.

Analisis Determinasi

Untuk mengetahui besarnya presentase pengaruh variabel yang diteliti rumus yang digunakan untuk menentukan koefesien determinasi (D) adalah $\mathrm{D}=\mathrm{R}^{2} \mathrm{x} 100 \%$. Besarnya $\mathrm{R}^{2}$ dapat diperoleh dari besarnya nilai koefesien $\mathrm{R}$ square. Hasil analisis determinasi dengan program SPSS, dapat dibuat seperti tabel 2 berikut ini.

Tabel 2. Model Summary

\begin{tabular}{|l|r|r|r|}
\hline Model & R & R Square & \multicolumn{1}{|c|}{$\begin{array}{c}\text { Adjusted R } \\
\text { Square }\end{array}$} \\
\hline 1 & $.959^{\mathrm{a}}$ & .919 & .912 \\
\hline
\end{tabular}

Sumber: Lampiran 10

Berdasarkan hasil analisis determinasi seperti pada tabel 4.9 di atas, maka dapat dihitung besarnya koefesien determinasi (D) sebesar 0,919 $\mathrm{x} 100 \%=91,9$. Dengan demikian dapat

Vol.13 No.11 Juni 2019 
dinyatakan bahwa kompetensi wirausaha, kreativitas dan penggunaan media sosial memiliki pengaruh sebesar 91,9 terhadap perkembangan usaha batu padas. Sedangkan sisanya sebesar $8,1 \%$ dipengaruhi oleh faktor lain yang tidak dibahas pada analisis ini.

\section{Uji hipotesis dengan Uji-t}

Uji hipotesis dengan uji $t$ ini digunakan untuk melakukan pengujian secara parsial nyata tidaknya pengaruh antara kompetensi wirausaha, kreativitas dan penggunaan media sosial terhadap perkembangan usaha batu padas secara sendirisendiri. Hasil analisis uji secara parsial dengan uji t disajikan seperti pada tabel 3 berikut ini.

Tabel 3. Hasil Uji Parameter Secara Parsial dengan Uji t

\begin{tabular}{|c|c|c|c|c|c|}
\hline \multirow{2}{*}{ Model } & \multicolumn{2}{|c|}{$\begin{array}{c}\text { Unstandardized } \\
\text { Coefficients }\end{array}$} & \multirow{2}{*}{$\begin{array}{c}\begin{array}{c}\text { Standardized } \\
\text { Coefficients }\end{array} \\
\text { Beta }\end{array}$} & \multirow{2}{*}{$\mathrm{T}$} & \multirow{2}{*}{ Sig. } \\
\hline & B & $\begin{array}{l}\text { Std. } \\
\text { Error }\end{array}$ & & & \\
\hline (Constant) & $|-1.326|$ & 1.233 & & -1.075 & -1.326 \\
\hline $\begin{array}{l}\text { Kompetensi } \\
\text { Wirausaha }\end{array}$ & .562 & .120 & .559 & 4.702 & .562 \\
\hline Kreativitas & .363 & .122 & .336 & 2.962 & .363 \\
\hline $\begin{array}{l}\text { Penggunaan Media } \\
\text { Sosial }\end{array}$ & .174 & .082 & .133 & 2.116 & .174 \\
\hline
\end{tabular}

Sumber: Hasil Pengolahan SPSS

Berdasarkan analisis data seperti pada tabel 4.10 di atas, maka berikut ini akan dianalisis signifikannya pengaruh masing-masing variabel bebas seperti berikut ini.

1. Menguji pengaruh Kompetensi Wirausaha $\left(\mathrm{X}_{1}\right)$ terhadap Perkembangan Usaha (Y).

a) Merumuskan hipotesis

Ho : $b_{1}=0$ artinya kompetensi wirausaha tidak berpengaruh terhadap perkembangan usaha batu padas.

Hi : $b_{1}>0$, artinya kompetensi wirausaha berpengaruh positif dan signifikan terhadap usaha batu padas.

b) Menentukan taraf Kreativitas $(\alpha)$ $5 \%(0,05)$ dan $\mathrm{df}=(\mathrm{n}-\mathrm{k})=36-4=32$, dengan uji sisi kanan maka diperoleh tabel sebesar 1,697 (Lampiran 11).

c) Kriteria pengujian

Kriteria pengujian hipotesis dilakukan dengan uji satu sisi yaitu uji sisi kanan.

Apabila $t_{\text {hitung }}>t_{\text {tabel }}$, maka Ho ditolak
Apabila $\mathrm{t}_{\text {hitung }} \leq \mathrm{t}_{\text {tabel, }}$, maka Ho diterima

d) Kesimpulan

Berdasarkan perhitungan data seperti pada tabel 4.10 di atas diperoleh besarnya nilai thitung untuk variabel kompetensi wirausaha sebesar 4,702 > $t_{\text {tabel }} 1,697$ dengan tingkat signifikansi 0,000 . Ini berarti secara parsial kompetensi wirausaha memiliki pengaruh yang signifikan terhadap perkembangan usaha batu padas Banjar Silakarang, Singapadu, Kecamatan Sukawati.

2. Menguji pengaruh Kreativitas $\left(\mathrm{X}_{2}\right)$ terhadap Perkembangan Usaha $(\mathrm{Y})$

a) Merumuskan hipotesis

Ho: $b_{2}=0$, artinya kreativitas tidak berpengaruh terhadap perkembangan usaha batu padas

Hi : $b_{2}>0, \quad$ artinya kreativitas berpengaruh positif dan signifikan terhadap perkembangan usaha batu padas

b) Menentukan taraf Kreativitas $(\alpha)$ $5 \%(0,05)$ dan $\mathrm{df}=(\mathrm{n}-\mathrm{k})=36-4=32$, dengan uji sisi kanan maka diperoleh ttabel sebesar 1,697 (Lampiran 11).

c) Kriteria pengujian

Kriteria pengujian

hipotesis dilakukan dengan uji satu sisi yaitu uji sisi kanan.

Apabila thitung $>t_{\text {tabel}}$, maka Ho ditolak

Apabila $t_{\text {hitung }} \leq \mathrm{t}_{\text {tabel }}$, maka Ho diterima

d) Kesimpulan

Berdasarkan perhitungan data seperti pada tabel 4.10 di atas diperoleh besarnya nilai thitung untuk variabel kreativitas sebesar 2,962 > $t_{\text {tabel }}$ 1,697 dengan tingkat signifikansi 0,006. Ini berarti secara parsial kreativitas memiliki pengaruh yang nyata terhadap perkembangan usaha batu padas Banjar Silakarang, Singapadu, Kecamatan Sukawati.

3. Menguji pengaruh Penggunaan media sosial $\left(\mathrm{X}_{3}\right)$ terhadap Perkembangan Usaha (Y)

a) Merumuskan hipotesis

Ho : $b_{3}=0, \quad$ artinya penggunaan media sosial tidak berpengaruh terhadap perkembangan usaha batu padas

http://ejurnal.binawakya.or.id/index.php/MBI 
$\mathrm{Hi}: \mathrm{b}_{3}>0, \quad$ artinya penggunaan media sosial berpengaruh positif dan signifikan terhadap perkembangan usaha batu padas

b) Menentukan taraf Penggunaan media sosial $(\alpha) 5 \%(0,05)$ dan $\mathrm{df}=(\mathrm{n}-\mathrm{k})=36-4$ $=32$, dengan uji sisi kanan maka diperoleh $t_{\text {tabel }}$ sebesar 1,697 (Lampiran 11).

c) Kriteria pengujian

Kriteria

pengujian

hipotesis dilakukan dengan uji satu sisi yaitu uji sisi kanan.

Apabila $t_{\text {hitung }}>t_{\text {tabel }}$, maka Ho ditolak

Apabila $t_{\text {hitung }} \leq t_{\text {tabel }}$, maka Ho diterima

d) Kesimpulan

Berdasarkan perhitungan data seperti pada tabel 4.10 di atas diperoleh besarnya nilai $t_{\text {hitung }}$ untuk variabel penggunaan media sosial sebesar $2,116>t_{\text {tabel }} 1,697$ dengan tingkat signifikansi 0,042. Ini berarti secara parsial penggunaan media sosial memiliki pengaruh yang nyata terhadap perkembangan usaha batu padas Banjar Silakarang, Singapadu, Kecamatan Sukawati.

\section{Pengaruh Kompetensi Wirausaha Terhadap Perkembangan UKM}

Diterimanya hipotesis pertama yang menyatakan kompetensi wirausaha berpengaruh positif dan signifikan terhadap perkembangan Usaha sejalan dengan hasil penelitian yang dilakukan oleh Yully Christina, dkk. (2014) yang menemukan bahwa seluruh variabel independen secara parsial, variabel kompetensi wirausaha (X1) berpengaruh terhadap perkembangan usaha (Y) sebesar 77,7\%, pembinaan usaha (X2) berpengaruh terhadap perkembangan usaha (Y) sebesar 23,9\%, dan inovasi produk (X3) berpengaruh terhadap perkembangan usaha $(\mathrm{Y})$ sebesar $66,5 \%$. Artinya kompetensi wirausaha memiliki hubungan yang cukup kuat dengan Perkembangan Usaha. Kompetensi wirausaha memberikan pengaruh sebesar $77,7 \%$ terhadap Perkembangan Usaha.

\section{Pengaruh Kreativitas Terhadap Perkembangan UKM}

Diterimanya hipotesis kedua yang menyatakan kreativitas berpengaruh positif dan signifikan terhadap perkembangan usaha sejalan http://ejurnal.binawakya.or.id/index.php/MBI dengan hasil penelitian yang dilakukan Siti Juhaeriah (2015). Berdasarkan hasil-hasil positif pelatihan pengembangan bisnis dengan thitung $(3,600)>$ ttabel $(1,697)$, pengaruh positif pengembangan bisnis dengan thitung $(3,185)>$ ttabel $(1,697)$ dan pengaruh positif pelatihan dan kreativitas terhadap pengembangan bisnis dengan Fcount (16.688)> Ftabel (3.316). Pengaruh dari dua variabel independen dapat ditentukan berdasarkan R2 dengan nilai 0,527. Ini, 52,7\% dari variasi dalam pengembangan bisnis dipengaruhi oleh model pelatihan dan kreativitas lainnya. Secara bersamaan, kekuatan hubungan antara variabel pengembangan bisnis, pelatihan dan kreativitas kuat, sebesar 0,726.

\section{Pengaruh Penggunaan Media Sosial Terhadap Perkembangan UKM}

Diterimanya hipotesis ketiga yang menyatakan Penggunaan media sosial berpengaruh positif dan signifikan terhadap perkembangan UKM sejalan dengan hasil penelitian yang dilakukan oleh Pratiwi (2010) yang menemukan bahwa peranan media sosial memiliki pengaruh yang positif dan signifikan terhadap pemakai kartu Simpati dan kartu XL di Kota Bekasi.

\section{PENUTUP \\ Kesimpulan}

Berdasarkan pembahasan yang telah diuraikan pada bab sebelumnya, maka diperoleh simpulan sebagai berikut.

1. Besarnya nilai thitung untuk variabel kompetensi wirausaha sebesar 4,702 > $t_{\text {tabel }}$ 1,697 dengan tingkat signifikansi 0,000. Ini berarti secara parsial kompetensi wirausaha memiliki pengaruh yang nyata terhadap perkembangan usaha batu padas Banjar Silakarang, Singapadu, Kecamatan Sukawati.

2. Besarnya nilai thitung untuk variabel kreativitas sebesar 2,962 > t tabel 1,697 dengan tingkat signifikansi 0,006. Ini berarti secara parsial kreativitas memiliki pengaruh yang nyata terhadap perkembangan usaha batu padas Banjar Silakarang, Singapadu, Kecamatan Sukawati.

\section{Open Journal Systems}


3. Besarnya nilai thitung untuk variabel penggunaan media sosial sebesar 2,116 $>t_{\text {tabel }}$ 1,697 dengan tingkat signifikansi 0,042. Ini berarti secara parsial penggunaan media sosial memiliki pengaruh yang nyata terhadap perkembangan usaha batu padas Banjar Silakarang, Singapadu, Kecamatan Sukawati.

\section{Saran}

Berdasarkan simpulan di atas, maka saran yang dapat penulis ajukan pada perajin batu padas Banjar Silakarang Singapadu Kecamatan Sukawati adalah:

1. Para perajin batu padas Banjar Silakarang Singapadu Kecamatan Sukawati perlu mendapat pelatihan dari dinas terkait, terutama dalam hal menganalisa usaha yang digelutinya. Selain itu pula para perajin batu padas perlu meningkatkan intensitas dalam mengadakan sosialisasi pelatihan terpadu mengenai pemahaman dalam menganalisa usaha.

2. Dinas terkait diharapkan dapat berperan aktif dalam melakukan monitoring dan evaluasi secara periodik, misalnya dilakukan setiap akhir bulan untuk mengetahui perkembangan batu padas pada khususnya dan pelaku-pelaku usaha lain pada umumnya.

3. Penggunaan media sosial perlu ditingkatkan lagi dalam promosi penjualan usaha batu padas Banjar Silakarang, Singapadu, Kecamatan Sukawati, agar usaha batu padas tersebut berkembang menjadi usaha batu padas dengan skala yang lebih besar.

\section{DAFTAR PUSTAKA}

[1] Aaker, David, 1996, Building Strong Brands, New York: The Free Press.

[2] Assael, Henry. 1984. Consumer Behavior and Marketing Action, 2nd ed., Boston, Massachusetts; Kent Publishing Co.

[3] Algifari. 2003. Statistika Induktif untuk Ekonmi dan Bisnis. AM YKPN. Yogyakarta

[4] Cravens, David W. 2013. Strategic marketing 10th ed. 658.802 C898 2013.

Vol.13 No.11 Juni 2019
[5] Devito, Joseph. 2011. Komunikasi Antar Manusia. Tanggerang Selatan. Karisma Publishing Group.

[6] Donald F. Kuratko \& Richard M.Hodgetts. 2004. Entrepreneurship: Theory, Process, 6 th Ed., Practice Thomson South Western

[7] Ebeid, A. Y. 2014. Distribution Intensity, Advertising, Monetary Promotion, and Customer-Based Brand Equity: An Applied study in Egypt. International Journal of Marketing Studies, 6(4), 113-122. https://doi.org/10.5539/ ijms.v6n4p113.

[8] Fandy, Tjiptono. 2008. Strategi Bisnis Pemasaran. Yogyakarta. Andi.

[9] Ghozali, Imam. 2006. Aplikasi Analisis Multivarite dengan SPSS, Cetakan Keempat. Semarang. Universitas Diponegoro.

[10]Hermawan, Agus. 2012. Komunikasi Pemasaran. Jakarta. Erlangga

[11]Ibnu, Widiyanto, 2008. Pointers: Metodologi Penelitian. Semarang. BP Undip.

[12] Marc J. Dollinger. 2003. Entrepreneurship: Strategies \& Resources. 2nd Ed. Person Education Inc.

[13] Nurgiyantoro, Singgih. 2014. Pengaruh Strategi Promosi Melalui Social Media Terhadap Keputusan Pembelian Garskin Yang Dimediasi Marketing (Studi Pada Konsumen Produk Garskin Merek Sayhello Di Kota Yogyakarta). Yogyakarta. Universitas Negeri Yogyakarta

[14]Peter, P, J, \& Olson, Jerry, C. 2009. Costumer Behavior, Jilid 2, Edisi Kelima (alih bahasa Damos Sihombing). Jakarta. Erlangga.

[15]Robert T. Kiyosaki. 2010. The Cashflow Quadrant. Cetakan keduapuluh. PT Gramedia Pustaka Utama

[16] Sernovitz, Andy. 2012. Word of Mouth Marketing. Amerika. Greenleaf Book Group Press.

[17] Solis, Brian. 2010. Engage: The Complete Guide for Brands and Business to Build, Cultivate, and Measure Success in the New Web. New Jersey. John Wiley \& Sons Inc.

http://ejurnal.binawakya.or.id/index.php/MBI 
[18] Sriwedari, Enggal. 2011. Word Of Mouth Sebagai Efek Respon Positif Dari Kepuasan Konsumen Dan Dampaknya Pada Pembelian Kembali: Studi Kasus Mahasiswa Sebagai Konsumen Yoghurt Activia. Jakarta. 2011

[19] Sugiyono. 2014. Metode Penelitian Pendidikan Pendekatan Kuantitatif, Kualitatif, dan R\&D. Alfabeta, Bandung.

[20] Sumardy, dkk. 2011. The Power of Word of Mouth Marketing.Jakarta. Gramedia Pustaka Utama.

[21] Supranto, dan Limakrisna, Nandan. 2011. Perilaku Konsumen dan Strategi Pemasaran, Edisi Kedua. Jakarta. Mitra Wacana Media.

[22] Sutisna. 2001. Perilaku Konsumen dan Komunikasi Pemasaran. Bandung. PT. Remaja Rosdakarya.

[23] Taprial, Varinder \& Kanwar, Priya. 2012. Understanding Social Media. London. Ventus Publishing Aps.

[24] Umar Husein. 2013. Metode Penelitian Untuk Skripsi dan Tesis Bisnis. Jakarta. PT. Rajagrafindo Persada

[25] Wenats, AG Eka dkk. 2012. Integrated Marketing Communications: Komunikasi Pemasaran di Indonesia. Jakarta. Gramedia Pustaka Utama. 
HALAMAN INI SENGAJA DIKOSONGKAN 